\title{
FSHR genotype affects estrogen levels but not pregnancy rates in Luxi cattle subjected to embryo transfer
}

\author{
W.C. Yang ${ }^{1,2}$, S.J. Li $^{3}$, L. Chen ${ }^{3}$ and L.G. Yang ${ }^{2}$ \\ ${ }^{1}$ College of Animal Science and Technology, \\ Northwest A\&F University, Shaanxi, China \\ ${ }^{2}$ Key Laboratory of Agricultural Animal Genetics, \\ Breeding and Reproduction of Ministry of Education, \\ Huazhong Agricultural University, Wuhan, China \\ ${ }^{3}$ Beijing Dairy Center, Beijing, China \\ Corresponding author: L.G. Yang \\ E-mail: 1592137597@qq.com
}

Genet. Mol. Res. 13 (1): 1563-1569 (2014)

Received January 3, 2013

Accepted June 29, 2013

Published March 12, 2014

DOI http://dx.doi.org/10.4238/2014.March.12.8

\begin{abstract}
Follicle-stimulating hormone receptor (FSHR), which mediates the functioning of FSH, plays a central role in reproduction. We investigated bovine FSHR gene polymorphisms and analyzed their relationships with pregnancy rates after embryo transfer and with hormone concentrations on the day of embryo transfer. One reported SNP of FSHR, G-278A, located in the 5'-upstream region, was analyzed and three genotypes (GG, GA and AA) were detected in 132 Luxi cattle recipients. Statistical analysis revealed that recipients with the GG genotype had significantly higher estrogen levels on the day of embryo transfer than did GA and AA genotypes. There were no significant differences in pregnancy rates among genotypes, after embryo transfer. We conclude that variation at these loci of the FSHR gene has no significant effect on pregnancy rates in Luxi cattle.
\end{abstract}

Key words: Luxi cattle; Embryo transfer; FSHR; Pregnancy rates 


\section{INTRODUCTION}

Embryo transfer (ET) has become the most powerful tool for animal breeders and animal scientists to improve the genetic makeup of their animal herds. However, embryonic survival rates after ET vary widely from 40 to $70 \%$ (Nishigai et al., 2002; Kawate et al., 2007); ET is an expensive, inefficient technology (Hasler, 2003). The success of ET is determined by many intrinsic and extrinsic factors, including season, breed, age, nutrition, management, stress, quality of gonadotrophin products, and treatment protocols (Thibier, 2008). Although the effects of intrinsic and extrinsic factors on the pregnancy rates of ET have been elucidated (Nishigai et al., 2002; Betteridge, 2006; Kawate et al., 2007; Wu and Zan, 2012), the conception rates following ET have changed very little over the years (Hasler, 2003). Candidate gene approach has been widely used in genetic association and biomarkers from animals to humans, and many candidate genes of animal reproduction traits have been detected (Cochran et al., 2013). Thus, it appears to be worthwhile to use candidate gene approach in recipient selection to identify potential markers that correlate with pregnancy rates after ET.

Follicle-stimulating hormone (FSH) is secreted by the anterior pituitary and plays a key role in normal reproductive function (Hsueh et al., 1989; Gharib et al., 1990; Howles, 2000). In the absence of sufficient FSH, follicles fail to develop beyond the early antral stage, leading to the failure of ovulation (Simoni et al., 1997; Erman and Oktay, 2009). Furthermore, normal levels are a must for the formation of the placenta and thus conception. FSH action must be mediated by FSH receptor (FSHR), a member of the family of G-protein-coupled receptors expressed solely in granulosa cells (Rannikki et al., 1995; Fan and Deng, 1998; Livshyts et al., 2009). Due to the important roles of FSH in follicular growth and ovarian steroidogenesis in females, mutations in the FSHR gene could affect reproductive ability. So far, a large number of mutations have been detected in the FSHR gene, which are associated with reproductive diseases in humans such as polycystic ovary syndrome (Whitney et al., 1995; Conway et al., 1999), ovarian dysgenesis, secondary amenorrhea, or partial FSH resistance syndrome (Beau et al., 1998; Touraine et al., 1999), and superovulation response in cows (Yang et al., 2010), as well as litter size in Small Tail Han sheep (Chu et al., 2012). However, whether the FSHR polymorphism has any effect on pregnancy rate is currently unknown.

Therefore, FSHR was chosen as a candidate gene to investigate the effects of its polymorphism on pregnancy rates after ET. PCR-RFLP analysis was used to detect variants of the bovine FSHR gene and evaluate its association with pregnancy rates to identify potential markers for recipient selection of ET.

\section{MATERIAL AND METHODS}

\section{Experimental cattle and sampling}

This study was conducted in Beijing Amber Embryo Technology Co. Ltd., Beijing, China. One hundred and thirty-two Luxi cows, unrelated in three generations, were recipients of embryos. Genomic DNA was extracted from blood samples using a phenolchloroform standard protocol. Blood samples without anticoagulant were allowed to clot overnight at room temperature, and the serum was frozen at $-20^{\circ} \mathrm{C}$ until it was assayed for $\mathrm{P}_{4}$ and $\mathrm{E}_{2}$ concentrations. 


\section{Synchronization of estrus in recipients}

One hundred and thirty-two Luxi cows received a CIDR device (New Zealand DEC Co., Ltd.) on random days of the estrous cycle (day 0 ), an injection of $0.6 \mathrm{mg}$ prostaglandin $\mathrm{F}_{2 \alpha}$ (Qilu Animal Health Products Co., Ltd., China) was given on day 9, and devices were removed on day 12. Estrus detection by visual observation was carried out on day 13, and embryos were transferred 6.5 to 8.5 days after detection of estrus.

\section{Embryo transfer}

Recipients were only used if they had been observed in standing estrus and possessed a palpable corpus luteum (CL) at the time of transfer. A single frozen-thawed Wagyu cattle embryo was transferred transcervically with a standard $1 / 4-\mathrm{mL}$ embryo transfer instrument into the uterine horn ipsilateral to the CL. All embryos were assigned a developmental stage and quality grade according to standards of the International Embryo Transfer Society (Savoy, IL, USA). Developmental stage codes were: $3=$ early morula; $4=$ morula; $5=$ early blastocyst; and, 6 = blastocyst. Quality codes were: $1=$ symmetrical and spherical embryo mass with individual blastomeres that were uniform in size, color, and density with at least $85 \%$ of the cellular material intact (excellent or good) and $2=$ moderate irregularities in overall shape of embryonic mass or in size, color and density of individual cells with at least $50 \%$ of the cellular material intact (fair). Embryos given stage codes less than 3 or greater than 6 or poor quality embryos (quality score of 3 or 4) were excluded from the study. Pregnancy diagnosis was performed 40 days after ET by ultrasonography.

\section{Primer synthesis and PCR conditions}

One reported SNP of FSHR G-278A (Yang et al., 2010) located in the 5'-upstream region was selected as a potential marker for pregnancy rates after ET. Primer sequences (F: 5'-TCCCTGCCCTTCAGTGACGAAC-3' and R: 5'-GATACGCCGTCCCTTTACCT-3') and reaction conditions for G-278A polymorphism were selected according to a previous study (Yang et al., 2010). PCR was performed in a total volume of $20 \mu \mathrm{L}$ containing $10 \mathrm{pmol}$ primers, $200 \mu \mathrm{M}$ dNTPs, $2 \mu \mathrm{L} 10 \mathrm{X}$ reaction buffer containing $1.5 \mathrm{mM} \mathrm{MgCl}_{2}, 0.5 \mathrm{U}$ Taq DNA polymerase (Promega, Madison, WI, USA), and $50 \mathrm{ng}$ genomic DNA as template. After denaturation at $94^{\circ} \mathrm{C}$ for $5 \mathrm{~min}, 34$ amplification cycles were performed comprising denaturation at $94^{\circ} \mathrm{C}$ for $45 \mathrm{~s}$, annealing at $64^{\circ} \mathrm{C}$ for $45 \mathrm{~s}$, and extension at $72^{\circ} \mathrm{C}$ for $45 \mathrm{~s}$, followed by a further $10 \mathrm{~min}$ extension at $72^{\circ} \mathrm{C}$. PCR products were electrophoretically detected on $1.5 \%$ agarose gel $(5 \mathrm{~V} / \mathrm{cm})$ by staining with GelRed.

\section{Genotyping}

To detect the SNP FSHR G-278A, the FSHR PCR products were digested with BsmFI (Yang et al., 2010) (TaKaRa, Tokyo, Japan). The digestion mixture contained $4 \mu \mathrm{L}$ PCR products, $1 \mathrm{X}$ digestion buffer and $3.0 \mathrm{U}$ of each enzyme, and was incubated at $37^{\circ} \mathrm{C}$ overnight. Fragments were separated on $2 \%$ agarose gels and visualized with GelRed staining. 


\section{Hormone assays by radioimmunoassay}

Serum concentrations of $\mathrm{P}_{4}$ and $\mathrm{E}_{2}$ of recipients on day of ET were measured by radioimmunoassay (Diagnostic Products Corporation, Beijing North Institute of Biotechnology, Beijing, China). Sensitivity was $\leq 3 \mathrm{pg} / \mathrm{mL}$ for $\mathrm{E}_{2}$ and $\leq 0.05 \mathrm{ng} / \mathrm{mL}$ for $\mathrm{P}_{4}$, whereas the intraand interassay coefficients of variation were respectively $<10$ and $<15 \%$ for each assay.

\section{Statistical analysis}

Gene frequencies were determined by direct counting and Hardy-Weinberg equilibrium was analyzed using the chi-square test by the SAS 8.1 software. Pregnancy rates among three genotypes of the FSHR gene were compared using the chi-square analysis. The differences between genotypes in the concentrations of $\mathrm{E}_{2}$ and $\mathrm{P}_{4}$ were analyzed by one-way ANOVA. All analyses were performed using the SAS software. Statistical significance was based on $\mathrm{P} \leq 0.05$. Data are reported as means $\pm \mathrm{SD}$.

\section{RESULTS}

\section{Genotypic and allelic frequencies}

Polymorphism of FSHR G-278A destroyed the restriction site recognized by endonuclease BsmFI and resulted in the three genotypes GG (128 and $83 \mathrm{bp})$, GA (211, 128 and 83 bp), AA (211 bp) (Figure 1). The frequency of the three genotypes showed a tendency of GA $>$ AA $>$ GG (Table 1), and this polymorphism was in Hardy-Weinberg equilibrium (Table 1).

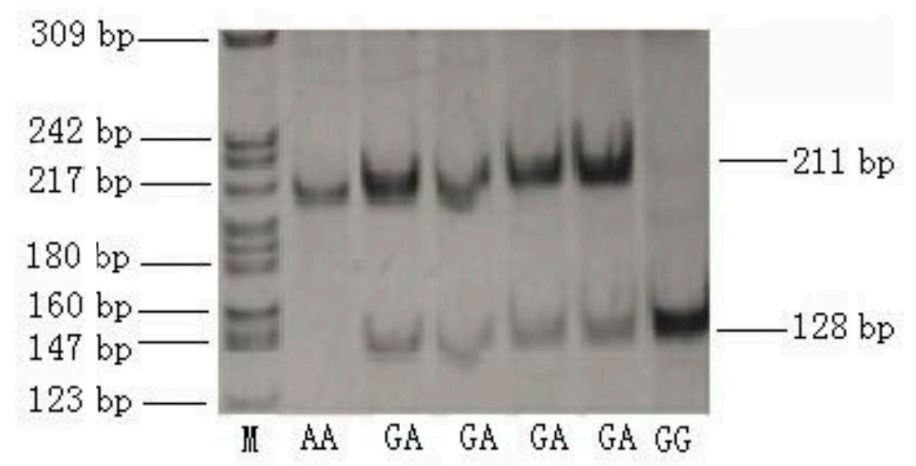

Figure 1. Representative genotyping of the FSHR gene at loci G-278A by a polyacrylamide gel electrophoresis. Lane $M=\mathrm{pBR} 322 \mathrm{DNA} / M s p$ I marker.

Table 1. Allelic and genotypic frequencies for FSHR G-278A mutation in Luxi cattle.

\begin{tabular}{lccccc}
\hline Locus & Genotype & Frequency & Allele & Frequency & $\chi^{2}$ value \\
\hline G-278A & GG (19) & 0.144 & G & 0.383 & $0.0179(\mathrm{P}>0.05)$ \\
& GA (63) & 0.477 & A & 0.617 & \\
& AA (50) & 0.379 & & & \\
\hline
\end{tabular}




\section{Effect of genotypes on pregnancy rates and hormone concentrations}

Pregnancy rates and concentrations of $\mathrm{E}_{2}$ and $\mathrm{P}_{4}$ on the day of ET with the different genotypes are presented in Tables 2 and 3. The G-278A mutation had no significant effect on pregnancy rate and concentrations of $\mathrm{E}_{2}$ and $\mathrm{P}_{4}$. However, recipients with the $\mathrm{GG}$ genotype had obviously higher $\mathrm{E}_{2}$ concentration on the day of ET compared to the GA and AA genotypes (Table 3).

Table 2. Pregnant rates of freezed embryo of different FSHR genotypes after being transferred.

\begin{tabular}{lcc}
\hline Genotype & No. transferred & Pregnant rate (\%) \\
\hline GG & 19 & $47.36(9 / 19)$ \\
GA & 63 & $49.20(31 / 63)$ \\
AA & 50 & $48.00(24 / 50)$ \\
\hline
\end{tabular}

Table 3. Effects of different FSHR genotypes on serum concentrations of estrogen and progesterone.
\begin{tabular}{lccc}
\hline Genotype & GG & GA & AA \\
\hline Estrogen $(\mathrm{pg} / \mathrm{mL})$ & $4.947 \pm 0.843$ & $3.367 \pm 0.453$ & $3.050 \pm 0.488$ \\
Progesterone $(\mathrm{ng} / \mathrm{mL})$ & $0.159 \pm 0.017$ & $0.164 \pm 0.016$ & $0.169 \pm 0.0127$ \\
\hline
\end{tabular}

\section{DISCUSSION}

\section{Polymorphisms of 5'-flanking region of the FSHR gene}

So far, a large number of mutations have been detected in the 5'-upstream region of the FSHR gene, which are associated with reproductive diseases or reproduction traits. In humans, the SNP G-29A in the 5'-upstream region of the FSHR gene has been detected in both women with primary and secondary amenorrhea in India (Achrekar et al., 2010) and infertile men in Southeast Turkey (Balkan et al., 2010). In goats, five mutations (C-93A, G-80C, C-63A, C-56G, and T-55C) have been identified in Xiangdong Black, Nanjiang Brown and Guizhou Black goats (Zhu et al., 2007), two SNPs (C-629T and T-681C) in Hu sheep, and three novel SNPs (G-200A, G-197A and T-98C) in Small Tail Han sheep in the 5'-upstream region of the FSHR gene (Chu et al., 2012), where these mutations are significantly associated with litter size traits. SNP G-278A was found in Chinese Holstein cows in our previous study (Yang et al., 2010), and also detected in Luxi cattle in this study.

\section{Effect of the FSHR gene on pregnancy rates and hormone concentrations}

Due to the important roles of FSH in normal reproductive functions, mutations in the FSHR gene could affect reproductive ability. During the last 10 years, many mutations have been identified in patients with polycystic ovary syndrome, ovarian dysgenesis, secondary amenorrhea, and partial FSH resistance syndrome, and functional studies have revealed that these mutations can affect proper protein folding, impair cell surface expression or alter signal transduction of the receptor (Whitney et al., 1995; Beau et al., 1998; Conway et al., 
1999; Achrekar et al., 2010). FSHR G-278A mutation has been identified in Chinese Holstein cows and significantly associated with superovulation traits (Yang et al., 2010). Through TFSEARCH predictions (Bray et al., 2003; Brudno et al., 2003), Yang et al. (2010) indicated that the G-278A in the 5'-upstream region of the bovine FSHR gene partly altered the binding sites of the transcription factor (Mayo et al., 2006). In the present study, G-278A mutation was detected in Luxi cattle, and statistical analysis revealed that this polymorphism had no significant effect on $\mathrm{E}_{2}$ and $\mathrm{P}_{4}$ concentrations. However, recipients with the GG genotype had a clearly higher $\mathrm{E}_{2}$ concentration on the day of ET than did the GA and AA genotypes. This may have contributed to the mutations in the 5'-upstream region, which partly altered the transcription factor binding sites and eventually resulted in a decreased level of FSHR gene expression by altering gene transcription, thereby decreasing the positive effect of FSH on the hypothalamus and anterior pituitary and finally decreasing the secretion of estrogen. Furthermore, the result revealed that G-278A mutation had no significant effect on pregnancy rate. Although G-278A mutation decreased the secretion of estrogen, it may still be in the normal range, which needs further verification.

In conclusion, the results of the present study preliminarily showed that the FSHR G278A mutation had no significant effect on pregnancy rate in Luxi cattle.

\section{ACKNOWLEDGMENTS}

Research supported by the Earmarked Fund for Modern Agro-Industry Technology Research System (\#nycytx-10) and Doctoral Fund of the Northwest A\&F University.

\section{REFERENCES}

Achrekar SK, Modi DN, Meherji PK, Patel ZM, et al. (2010). Follicle stimulating hormone receptor gene variants in women with primary and secondary amenorrhea. J. Assist. Reprod. Genet. 27: 317-326.

Balkan M, Gedik A, Akkoc H, Izci AO, et al. (2010). FSHR single nucleotide polymorphism frequencies in proven fathers and infertile men in Southeast Turkey. J. Biomed. Biotechnol. 2010: 640318.

Beau I, Touraine P, Meduri G, Gougeon A, et al. (1998). A novel phenotype related to partial loss of function mutations of the follicle stimulating hormone receptor. J. Clin. Invest. 102: 1352-1359.

Betteridge KJ (2006). Farm animal embryo technologies: achievements and perspectives. Theriogenology 65: 905-913.

Bray N, Dubchak I and Pachter L (2003). AVID: A global alignment program. Genome Res. 13: 97-102.

Brudno M, Do CB, Cooper GM, Kim MF, et al. (2003). LAGAN and Multi-LAGAN: efficient tools for large-scale multiple alignment of genomic DNA. Genome Res. 13: 721-731.

Chu MX, Guo XH, Feng CJ, Li Y, et al. (2012). Polymorphism of 5' regulatory region of ovine FSHR gene and its association with litter size in Small Tail Han sheep. Mol. Biol. Rep. 39: 3721-3725.

Cochran SD, Cole JB, Null DJ and Hansen PJ (2013). Discovery of single nucleotide polymorphisms in candidate genes associated with fertility and production traits inHolstein cattle. BMC Genet. 14: 49.

Conway GS, Conway E, Walker C, Hoppner W, et al. (1999). Mutation screening and isoform prevalence of the follicle stimulating hormone receptor gene in women with premature ovarian failure, resistant ovary syndrome and polycystic ovary syndrome. Clin. Endocrinol. 51: 97-99.

Erman AM and Oktay K (2009). Falling FSH levels predict poor IVF pregnancy rates in patients whom the gonadotropins are withheld. Arch. Gynecol. Obstet. 280: 761-765.

Fan J and Deng XH (1998). Advance on follicle stimulating hormone. Reprod. Contracept. 18: 122-125.

Gharib SD, Wierman ME, Shupnik MA and Chin WW (1990). Molecular biology of the pituitary gonadotropins. Endocr. Rev. 11: 177-199.

Hasler JF (2003). The current status and future of commercial embryo transfer in cattle. Anim. Reprod. Sci. 79: 245-264. Howles CM (2000). Role of LH and FSH in ovarian function. Mol. Cell Endocrinol. 161: 25-30. 
Hsueh AJ, Bicsak TA, Jia XC, Dahl KD, et al. (1989). Granulosa cells as hormone targets: the role of biologically active follicle-stimulating hormone in reproduction. Recent Prog. Horm. Res. 45: 209-273.

Kawate N, Sakase M, Watanabe K, Fukushima M, et al. (2007). Ovsynch plus CIDR protocol for timed embryo transfer in suckled postpartum Japanese Black beef cows. J. Reprod. Dev. 53: 811-817.

Livshyts G, Podlesnaja S, Kravchenko S, Sudoma I, et al. (2009). A distribution of two SNPs in exon 10 of the FSHR gene among the women with a diminished ovarian reserve in Ukraine. J. Assist. Reprod. Genet. 26: 29-34.

Mayo AE, Setty Y, Shavit S, Zaslaver A, et al. (2006). Plasticity of the cis-regulatory input function of a gene. PLoS Biol. 4: e45.

Nishigai M, Kamomae H, Tanaka T and Kaneda Y (2002). Improvement of pregnancy rate in Japanese Black cows by administration of hCG to recipients of transferred frozen-thawed embryos. Theriogenology 58: 1597-1606.

Rannikki AS, Zhang FP and Huhtaniemi IT (1995). Ontogeny of follicle-stimulating hormone receptor gene expression in the rat testis and ovary. Mol. Cell Endocrinol. 107: 199-208.

Simoni M, Gromoll J and Nieschlag E (1997). The follicle-stimulating hormone receptor: biochemistry, molecular biology, physiology, and pathophysiology. Endocr. Rev. 18: 739-773.

Thibier M (2008). The worldwide activity in farm animals embryo transfer. Embryo Transfer Newsletter 26: 4-9.

Touraine P, Beau I, Gougeon A, Meduri G, et al. (1999). New natural inactivating mutations of the follicle-stimulating hormone receptor: correlations between receptor function and phenotype. Mol. Endocrinol. 13: 1844-1854.

Whitney EA, Layman LC, Chan PJ, Lee A, et al. (1995). The follicle-stimulating hormone receptor gene is polymorphic in premature ovarian failure and normal controls. Fertil. Steril. 64: 518-524.

Wu B and Zan L (2012). Enhance beef cattle improvement by embryo biotechnologies. Reprod. Domest. Anim. 47: 865-871.

Yang WC, Li SJ, Tang KQ, Hua GH, et al. (2010). Polymorphisms in the 5' upstream region of the FSH receptor gene, and their association with superovulation traits in Chinese Holstein cows. Anim. Reprod. Sci. 119: 172-177.

Zhu J, Yang SL, Ouyang XX, Liu HX, et al. (2007). Relationship between polymorphism of follicle stimulating hormone receptor gene and litter size traits in goats. Grass Feed Livest.12-15. 